\title{
European Marine Biology Symposia
}

1st European Marine Biology Symposium

Helgoland, Federal Republic of Germany, 26 Sept.-1 Oct. 1966, Biologische Anstalt Helgoland

Topics: - Experimental ecology, its significance as a marine biological tool

- Subtidal ecology particularly as studied by diving techniques

- The food web in the sea

Helgoländer wissenschaftliche Meeresuntersuchungen 15 (1967), 721 pp. Editors:

O. Kinne \& H. Aurich.

2nd European Marine Biology Symposium

Bergen, Norway, 24-28 Aug. 1967, Biological Station, Espegrend

Topic: - The importance of water movements for biology and distribution of marine organisms

Sarsia 34 (1968), 398 pp. Editor: H. Brattström.

\section{3rd European Marine Biology Symposium}

Arcachon, France, 2-7 Sept. 1968, Station Biologique d'Arcachon

Topics: - Biologie des sédiments meublés (Vol. 1)

- Biologie des eaux à salinité variable (Vol. 2)

Vie et Milieu, Suppl. 22 (1971), Vol. 1: 464 pp., Vol. 2: 464-857 pp. Editor: J. Soyer.

4th European Marine Biology Symposium

Bangor, North Wales, U.K., 14-20 Sept. 1969, Marine Science Laboratories, University College of North Wales, Menai Bridge

Topics: - Larval biology

- Light in the marine environment

Cambridge University Press, London (1971), 599 pp. Editor: D. J. Crisp.

5th European Marine Biology Symposium

Venice, Italy, 5-11 Oct. 1970, Institute of Marine Biology, Venice

Topics: - Evolutionary aspects of marine biology

- Factors affecting biological equilibria in the Adriatic brackish water lagoons

Piccin, Padua (1972), 348 pp., Editor: B. Battaglia. 
6th European Marine Biology Symposium

Rovinj, Yugoslavia, 27 Sept.-2 Oct. 1971, Marine Biological Station (Center for Marine Research of the Rudjer Boskovic Institute), Rovinj

Topics: - Productivity in coastal areas of the sea

- Dynamics in benthic communities

Thalassia Jugoslavica 7 (1971), 445 pp. Editor: D. Zavodnik.

\section{7th European Marine Biology Symposium}

Texel, The Netherlands, 11-16 Sept. 1972, The Netherlands Institute for Sea Research, Texel

Topics: - Mechanisms of migration in the marine environment

- Respiratory gases and the marine organism

Netherlands Journal of Sea Research 7 (1973), 505 pp. Editor: J. W. de Blok.

8th European Marine Biology Symposium

Sorrento, Italy, 1-7 Oct. 1973, Zoological Station of Naples

Topic: - Reproduction and sexuality in the marine environment

Pubblicazioni della Stazione Zoologica di Napoli 39, Suppl. 1 (1975), 727 pp.

Editors: G. Bonaduce \& G. C. Carrada.

\section{9th European Marine Biology Symposium}

Oban, Scotland, U.K., 2-8 Oct. 1974, The Dunstaffnage Marine Research Laboratory, Oban

Topic: - The biochemistry, physiology and behaviour of marine organisms in relation to their ecology

Aberdeen University Press, Aberdeen (1975), 760 pp. Editor: H. Barnes.

10th European Marine Biology Symposium

Ostend, Belgium, 17-23 Sept. 1975, Institute for Marine Scientific Research, Bredene

Topics: - Research in mariculture at laboratory- and pilot scale (Vol. 1)

- Population dynamics of marine organisms in relation with nutrient cycling in shallow waters (Vol. 2)

Universa Press, Wetteren (1976), Vol. 1: 620 pp., Vol. 2: 710 pp. Editors: G. Persoone \& E. Jaspers.

11th European Marine Biology Symposium

Galway, Ireland, 5-11 Oct. 1976, University College, Galway

Topic: - Biology of benthic organisms

Pergamon Press, Oxford (1977), 630 pp. Editors: B. F. Keegan, P. O'Ceidigh \& P. J. S. Boaden. 
12th European Marine Biology Symposium

Stirling, Scotland, U.K., 5-12 Sept. 1977, University of Stirling

Topic: - Physiology and behaviour of marine organisms

Pergamon Press, Oxford (1978), 388 pp. Editors: D. S. McLusky \& A. J. Berry.

13th European Marine Biology Symposium

Isle of Man, U.K., 27 Sept.-4 Oct. 1978, University of Liverpool, Port Erin

Topic: - Cyclic phenomena in marine plants and animals

Pergamon Press, Oxford (1979), 477 pp. Editors: E. Naylor \& R. G. Hartnoll.

14th European Marine Biology Symposium

Helgoland, Federal Republic of Germany, 23 Sept.-29 Sept. 1979, Biologische Anstalt Helgoland

Topic: - Protection of life in the sea

Helgoländer Meeresuntersuchungen 33 (1980), 732 pp. Editors: O. Kinne \& H.-P. Bulnheim. 